\title{
Isolation and Diagnosis of Bacillus sp From The Rhizosphere of Halophytic Wild Plants and Evaluation of The Efficiency of Isolates in Dissolving Tri-Calcium Phosphate
}

\author{
Saad Ali Hussein Al-Akabi ${ }^{1, a)}$, Najim A. Jumah Al-Zubaidy ${ }^{1, b)}$ and Faris Mohammad Suhail ${ }^{2, c)}$ \\ ${ }^{1}$ College of Education for Pure Sciences, University of Diyala, Iraq. \\ ${ }^{2}$ College of Agriculture, University of Diyala, Iraq. \\ a) Corresponding Author: d.saadalihussen@gmail.com \\ ${ }^{b)}$ drnajm2014@gmail.com \\ ${ }^{c)}$ dr.faris_63@yahoo.com
}

Received : $19 / 10 / 2021$

Acceptance : 26/11/2021

Available online: $31 / 12 / 2021$

\begin{abstract}
Bacillus sp was isolated and diagnosed from the rhizosphere of halophytic wild plants (Schanginia aeguptiace plant, Atriplex halimus plant, and the comparison soil far from the effect of the roots) and during three stages of plants growth (germination stage, vegetative growth stage, stage post flowering), and for three locations that included (Diyala University, Muqdadiya, Baladrooz) during the season of 2020. The diagnosis included studying the phenotypic, microscopic and biochemical features of these isolates and testing their efficiency in dissolving Tricalcium phosphate $\mathrm{Ca}_{3}\left(\mathrm{po}_{4}\right)_{2}$ as a source of phosphate after growing them in liquid and solid Pikovskayas media and estimating its solubility factor, and its efficiency in changing the degree of the medium reaction. The results of isolation and diagnosis showed the spread of Bacillus sp in saline environments, as 7 isolates out of 27 isolates that isolated during the growth stages of different halophytic wild plants were belonged to Bacillus subtilis, viz (B1, B5, B6, B7, B11, B15, B18, B19, B22, B23, B26), while the rest of the isolates belonged to Bacillus megaterium, whereas the isolates B1 and B2 were recorded the highest solubility factor reached (1.40 and 1.50) respectively, the isolate B26 was able to reduce the $\mathrm{pH}$ value of the inoculated medium to 4.81 .
\end{abstract}

Keywords. Bacillus subtilis, Bacillus megaterium, Schanginia aeguptiace, Atriplex halimus.

\section{INTRODUCTION}

Bacillus species spread in different environments and generally in soils because of their physiological capabilities that allow them to flourish in ecosystems and compete with other organisms within the environment, also due to their ability to form endospores that are highly resistant to environmental conditions such as heat, humidity, drought and salts [1,2]. The genus Bacillus was discovered early by the scientist Ehrenberg in 1835 and called it Vibrio suptilis, then it was changed to Bacteridium by Davaine in 1864, but the scientist Cohn proposed in 1872 the term Bacillus as a new nomenclature for this genus [3]. The cells of genus Bacillus are described as slightly curved rod-shaped cells, singly or in pairs or chains, sometimes resembling long filaments, Gram-positive in the early stages of growth, forming endospores that are motile by peritrichous flagella, facultatively aerobic or anaerobic, some of their species resemble anaerobe bacteria [4], do not need complex media for their growth, as they grow on normal media such as Nutrient agar and Pikovskaya medium (1948) that is modified by [5]. The dimensions of its cells range between 0.3-2.2 $\mu \mathrm{m}$ in width and 1.2-7 $\mu \mathrm{m}$ in length, producing the lactase enzyme, and some of its types are positive for the production of oxidase, spread in most environments, water, soil, air, food, plants, animals and medical samples. Its spores are resistant to drought, radiation, antiseptics and heat, due to they contain Dipicolinic acid ranging from 5 to $15 \%$ of the dry weight [6], and they are used in agricultural biological applications such as B.megaterim and the use of B.cereus in the production of polyhydroxybutyrate with industrial and medical uses [7]. Others cause food poisoning, such as B.cereus and B.subtilis [8]. [4] indicated during the isolation and diagnosis of B. subtilis and testing its efficiency in dissolving Tri-Calcium Phosphate in liquid cultures, as 25 samples were collected from the rhizosphere soil of different plants (barley, tomatoes, alfalfa, wheat, beans and maize), and the results showed the presence of ten isolates, which was diagnosed based on phenotypic, agronomic and biochemical characteristics, it has the ability to dissolve solid Tri-Calcium Phosphate in Nutrient Broth medium, the highest rate of soluble phosphorus for the two best

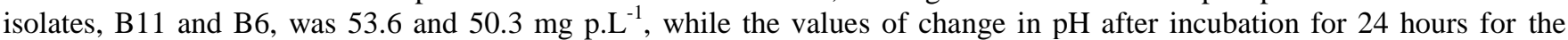
isolates were 6.5 and 6.9 respectively, which were superior on the other isolates, [9] showed that species of Bacillus genus have the ability to dissolve calcium phosphate at a rate of $50 \mu \mathrm{g} \mathrm{ml}^{-1}$, while the amount of phosphorous dissolved by a type of Streptomyces was $29 \mu \mathrm{g} \mathrm{ml}^{-1}$. 


\section{II.MATERIALS AND METHODS}

Twenty-seven samples were collected from the rhizosphere soil of Schanginia aeguptiace plant, Atriplex halimus plant, and the comparison soil far from the effect of the roots for three locations that included (University of Diyala, Muqdadiya, Baladrooz) and during three stages of growth of halophytic wild plants. The samples were placed in sterile polyethylene bags with alcohol and kept until use. Dilutions were made for each soil sample by adding $10 \mathrm{~g}$ of soil samples to $90 \mathrm{ml}$ of sterile distilled water in a beaker $250 \mathrm{ml}$ and mixing well, then sequential dilutions were made $10^{-1}$ to $10^{-7}$ by transferring $1 \mathrm{ml}$ of soil suspension to test tubes containing $9 \mathrm{ml}$ of sterile distilled water for each soil sample. Dishes containing solid Pikovskaya agar media and sealed tubes containing Pikovskaya liquid medium were inoculated with $0.1 \mathrm{ml}$ from dilutions $10^{-5}, 10^{-6}, 10^{-7}$, then the dishes were incubated at $30{ }^{\circ} \mathrm{C}$ for 48 hours, the developing colonies were counted, while the tubes were incubated in the vibrating incubator at the same temperature and for the same period of time in order to be used in biochemical tests [10].

- Diagnosis of Bacillus spp.

It relied on the diagnostic diagram of Bacillus, as stated in [11] and as showed in (Figure 1).

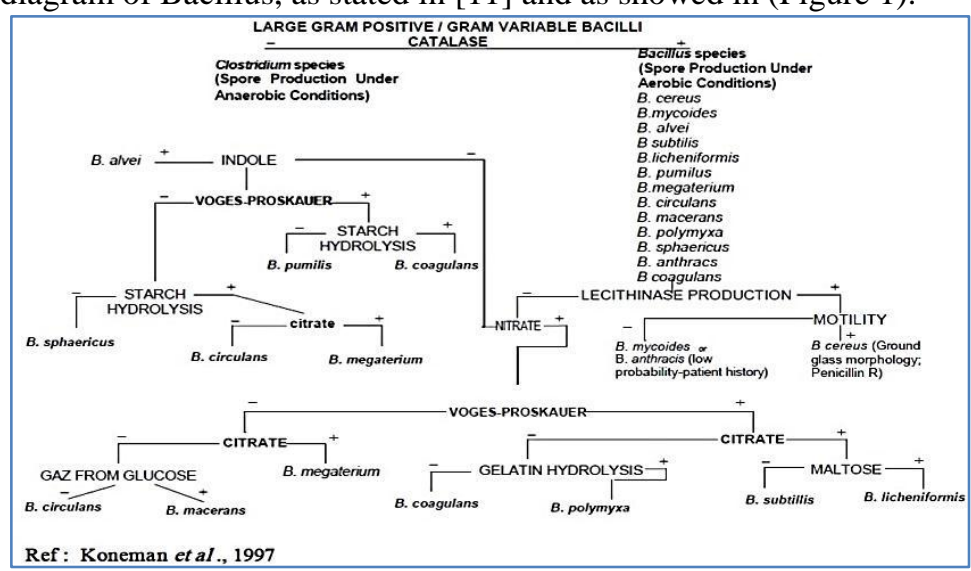

FIGURE 1. Diagnostic diagram of Bacillus spp.

- $\quad$ Phenotypic features

The phenotypic features of the growing colonies on solid Pikovskaya agar medium were recorded as reported [10].

- Microscopic features

A part of a colony was transferred by a sterile loop to a glass slide, then fix it and stain it with gram dye in order to observe the shapes and sizes of cells, the method of their assembly, formation the cover and the interaction with the dye as mentioned by [12].

- $\quad$ Motility test

The motility test was carried out after growing Bacillus sp on Nutrient Broth by using the hanging drop technique as mentioned in [12].

- Biochemical tests

- Starch hydrolysis test

Starch hydrolysis medium was prepared from $10 \mathrm{~g}$ starch, $3 \mathrm{~g}$ beef extract, $12 \mathrm{~g}$ agar, $1000 \mathrm{ml}$ sterile distilled water by adjusting $\mathrm{pH}$ at 7 , and poured in dishes, then inoculated with all bacterial isolates separately and incubated at $32{ }^{\circ} \mathrm{C}$ for 48 hours. The starch hydrolysis was observed after adding iodine solution with amount that covered the growing colony, the dishes were left for 30 seconds, then the iodine solution was poured, and the dishes were left for 2-3 minutes to dry. The appearance of a transparent halo around the colony is a positive test result [13]. A dilute iodine solution was prepared in a test of starch hydrolysis by dissolving $2 \mathrm{~g}$ of potassium iodide in $300 \mathrm{ml}$ of sterile distilled water.

\section{- $\quad$ Citrate consumption test}

The dishes containing Simmon citrate medium were inoculated with the different bacterial isolates and incubated at $32^{\circ} \mathrm{C}$ for 48 hours, then the dishes were checked, where if the color of the medium was changed from green to blue is a positive result of consuming the citrate, as the only carbon source [14].

- Gelatin liquefaction test

The gelatin $12 \%$ was added to the Nutrient Broth medium and the $\mathrm{pH}$ was adjusted at 7.2 , and the medium was distributed into test tubes with add $5 \mathrm{ml}$ for each tube, then the tubes were inoculated from the different isolates by stabbing method with bacterial culture, the tubes were incubated at a temperature of $32^{\circ} \mathrm{C}$ for 7 days, then placed in the refrigerator for an hour, where it was noticed that the liquefaction of gelatin is evidence of bacterial production to gelatinase enzyme and hydrolysis of gelatin [15]. 
- $\quad$ Oxidase enzyme test

The dishes containing Pikovskaya agar medium were inoculated with the different bacterial isolates and incubated at $32^{\circ}$ $\mathrm{C}$ for 24 hours, then drops of Oxidase reagent were added to the growing colonies, an appearance of the violet color of the colonies is a positive result of this test [16].

- Catalase test

A drop of the different isolates was placed on a sterile glass slide and a drop of hydrogen peroxide solution $3 \%$ was added. The appearance of air bubbles on the surface of the colony is a positive result of this test [17].

- $\quad$ Growth test in the saline concentration $\mathrm{NaCl} 7 \%$

The concentration $7 \%$ of sodium chloride was added to the solid Pikovskaya agar medium and the $\mathrm{pH}$ was adjusted at 7 , then the dishes were inoculated with the different isolates and the dishes were incubated at $32{ }^{\circ} \mathrm{C}$ for 48 hours. The appearance of the colonies is a positive result of tolerance to the level of salinity [16].

- $\quad$ Acidity tolerance test

Nutrient Broth medium with $\mathrm{pH}$ numbers (5, 7 and 10) was used and distributed in dishes, then were inoculated with the different isolates and incubated at $32^{\circ} \mathrm{C}$ for 48 hours, the appearance of the colonies is a positive result [13].

- Growth in temperature $55^{\circ} \mathrm{C}$

The tubes containing nutrient broth medium were inoculated with the different bacterial isolates and incubated at $55^{\circ} \mathrm{C}$ for 48 hours. The appearance of membranes near the surface of the medium is a positive result of the isolates' ability to grow at high temperatures [18].

- $\quad$ Carbohydrate fermentation test (glucose and maltose)

The medium was prepared by dissolving $1 \mathrm{~g}$ peptone, $0.1 \mathrm{~g}$ Beef extract, $0.5 \mathrm{~g} \mathrm{NaCl}$, and $0.0018 \mathrm{~g}$ Phenol red in $1000 \mathrm{ml}$ sterile distilled water, and adjusted $\mathrm{pH}$ to 7.4, carbohydrates were added separately and sterilized through a fine filter, then added to the medium, the medium was distributed into test tubes with add $5 \mathrm{ml}$ for each tube, then inoculated with the different isolates and incubated at $32^{\circ} \mathrm{C}$ for 2-3 days. Changing the color of the medium to yellow is an indication of carbohydrate consumption and acid production [16].

- $\quad$ Testing the efficiency of Bacillus sp isolates in dissolving phosphate in the solid culture medium

The dishes containing solid Pikovskaya agar medium with $\mathrm{Ca}_{3}(\mathrm{PO} 4)_{2}$ as a source of phosphorous were inoculated with the different isolates and incubated at $28^{\circ} \mathrm{C}$ for 48 hours, the solubility coefficient was estimated by applying the equation proposed by [19] that the appearance of a transparent halo around the colony is evidence of dissolving phosphate.

Solubilization coefficient $=$ (total diameter of the colony + diameter of the transparent halo / diameter of the colony only).

- $\quad$ Testing the efficiency of Bacillus sp isolates in changing the pH value of the medium

The liquid Pikovskaya medium was prepared and sterilized with an autoclave device at a temperature of $121{ }^{\circ} \mathrm{C}$ for a period of 15 minutes and a pressure of 15 pounds $/ \mathrm{inch}^{2}$, the medium was distributed into test tubes and inoculated by adding $1 \mathrm{ml}$ of the different isolates separately, and the tubes were incubated at $32^{\circ} \mathrm{C}$ for 5 days, the $\mathrm{pH}$ of the medium was estimated with the device of a $\mathrm{pH}$ meter [18].

\section{III.RESULTS AND DISCUSSION}

- $\quad$ Isolation of Bacillus spp

The results of the isolation showed that all the soil samples and during the different age stages of the halophyte wild plants were contained Bacillus spp. Twenty seven bacterial isolates were obtained, where Table (1) shows the symbol of the isolates and their collection locations, which were isolated during the stages of plant growth.

TABLE 1. The symbol of isolates Bacillus sp and their collection locations during the growth stages of halophytes wild plants.

\begin{tabular}{|c|c|c|c|c|}
\hline & $\begin{array}{c}\begin{array}{c}\text { Isolation } \\
\text { symbol }\end{array} \\
\end{array}$ & Collection region & Growth stage & $\begin{array}{c}\text { Collection } \\
\text { location }\end{array}$ \\
\hline 1 & B1 & $\begin{array}{l}\text { Rhizosphere of } S . \\
\text { aeguptiace }\end{array}$ & Germination & $\begin{array}{r}\text { Diyala } \\
\text { university }\end{array}$ \\
\hline 2 & B2 & $\begin{array}{l}\text { Rhizosphere of } A \text {. } \\
\quad \text { halimus }\end{array}$ & Germination & $\begin{array}{r}\text { Diyala } \\
\text { university }\end{array}$ \\
\hline 3 & B3 & A comparison soil & Germination & $\begin{array}{r}\text { Diyala } \\
\text { university }\end{array}$ \\
\hline 4 & B4 & $\begin{array}{l}\text { Rhizosphere of } S . \\
\text { aeguptiace }\end{array}$ & Germination & Muqdadiya \\
\hline 5 & B5 & $\begin{array}{l}\text { Rhizosphere of } A . \\
\text { halimus }\end{array}$ & Germination & Muqdadiya \\
\hline 6 & B6 & A comparison soil & Germination & Muqdadiya \\
\hline 7 & B7 & $\begin{array}{l}\text { Rhizosphere of } S . \\
\text { aeguptiace }\end{array}$ & Germination & Baladrooz \\
\hline & Isolation & Collection region & Growth stage & Collection \\
\hline
\end{tabular}




\begin{tabular}{|c|c|c|c|c|}
\hline \multicolumn{2}{|c|}{ symbol } & & \multicolumn{2}{|r|}{ location } \\
\hline 8 & B8 & $\begin{array}{l}\text { Rhizosphere of } A \text {. } \\
\text { halimus }\end{array}$ & Germination & Baladrooz \\
\hline 9 & B9 & A comparison soil & Germination & Baladrooz \\
\hline 10 & B10 & $\begin{array}{l}\text { Rhizosphere of } S \text {. } \\
\text { aeguptiace }\end{array}$ & $\begin{array}{l}\text { Vegetative } \\
\text { growth }\end{array}$ & $\begin{array}{r}\text { Diyala } \\
\text { university }\end{array}$ \\
\hline 11 & B11 & $\begin{array}{l}\text { Rhizosphere of } A . \\
\text { halimus }\end{array}$ & $\begin{array}{l}\text { Vegetative } \\
\text { growth }\end{array}$ & $\begin{array}{r}\text { Diyala } \\
\text { university }\end{array}$ \\
\hline 12 & B12 & A comparison soil & $\begin{array}{l}\text { Vegetative } \\
\text { growth }\end{array}$ & $\begin{array}{r}\text { Diyala } \\
\text { university }\end{array}$ \\
\hline 13 & B13 & $\begin{array}{l}\text { Rhizosphere of } S \text {. } \\
\text { aeguptiace }\end{array}$ & $\begin{array}{l}\text { Vegetative } \\
\text { growth }\end{array}$ & Muqdadiya \\
\hline 14 & B14 & $\begin{array}{l}\text { Rhizosphere of } A . \\
\text { halimus }\end{array}$ & $\begin{array}{l}\text { Vegetative } \\
\text { growth }\end{array}$ & Muqdadiya \\
\hline 15 & B15 & A comparison soil & $\begin{array}{l}\text { Vegetative } \\
\text { growth }\end{array}$ & Muqdadiya \\
\hline 16 & B16 & $\begin{array}{l}\text { Rhizosphere of } S \text {. } \\
\text { aeguptiace }\end{array}$ & $\begin{array}{l}\text { Vegetative } \\
\text { growth }\end{array}$ & Baladrooz \\
\hline 17 & B17 & $\begin{array}{l}\text { Rhizosphere of } A . \\
\text { halimus }\end{array}$ & $\begin{array}{l}\text { Vegetative } \\
\text { growth }\end{array}$ & Baladrooz \\
\hline 18 & B18 & A comparison soil & $\begin{array}{l}\text { Vegetative } \\
\text { growth }\end{array}$ & Baladrooz \\
\hline 19 & B19 & $\begin{array}{l}\text { Rhizosphere of } S \text {. } \\
\text { aeguptiace }\end{array}$ & Post flowering & $\begin{array}{r}\text { Diyala } \\
\text { university }\end{array}$ \\
\hline 20 & B20 & $\begin{array}{l}\text { Rhizosphere of } A . \\
\quad \text { halimus }\end{array}$ & Post flowering & $\begin{array}{r}\text { Diyala } \\
\text { university }\end{array}$ \\
\hline 21 & B21 & A comparison soil & Post flowering & $\begin{array}{r}\text { Diyala } \\
\text { university }\end{array}$ \\
\hline 22 & B22 & $\begin{array}{l}\text { Rhizosphere of } S \text {. } \\
\text { aeguptiace }\end{array}$ & Post flowering & Muqdadiya \\
\hline 23 & B23 & $\begin{array}{l}\text { Rhizosphere of } A . \\
\text { halimus }\end{array}$ & Post flowering & Muqdadiya \\
\hline 24 & B24 & A comparison soil & Post flowering & Muqdadiya \\
\hline 25 & B25 & $\begin{array}{l}\text { Rhizosphere of } S \text {. } \\
\text { aeguptiace }\end{array}$ & Post flowering & Baladrooz \\
\hline 26 & B26 & $\begin{array}{l}\text { Rhizosphere of } A . \\
\text { halimus }\end{array}$ & Post flowering & Baladrooz \\
\hline 27 & $\mathrm{~B} 27$ & A comparison soil & Post flowering & Baladrooz \\
\hline
\end{tabular}

- $\quad$ Diagnosis of Bacillus spp.

Table (2) showed the phenotypic, microscopic and biochemical characteristics of isolates grown in liquid and solid Pikovskayas media at a temperature of $30^{\circ} \mathrm{C}$ and an incubation period for three days [10], where the colonies were characterized by a gradation of colors from white and transparent white to yellow and creamy yellow, medium to large in size, circular, irregular, with a circular edge, lobed, serrated, slightly convex, smooth and shiny, as shown in Figure (2). The results of the microscopic test showed Bacillus spp is rod-shaped, gram-positive, single and some of them are in the form of chains and rarely found in pairs, mobile, forming a transparent halo around the colonies growing on solid Pikovskayas medium containing triple calcium phosphate as a source of phosphate of varying diameters, evidence of the bacteria's ability to dissolve phosphates, as well as their ability to change the $\mathrm{pH}$ value of the liquid culture medium $\mathrm{pH}(7.0)$ to the acidic medium due to its production of many organic acids. It also has the ability to grow in media with different $\mathrm{pH}(10,7,5)$, in addition to its growth in the medium containing $\mathrm{NaCl} 7 \%$, positive for oxidase and catalase test and some of its types are negative for it, and based on what was mentioned, these characteristics correspond with the microscopic and phenotypic characteristics of the genus Bacillus spp, and this is consistent with [20,4,7,18]. 


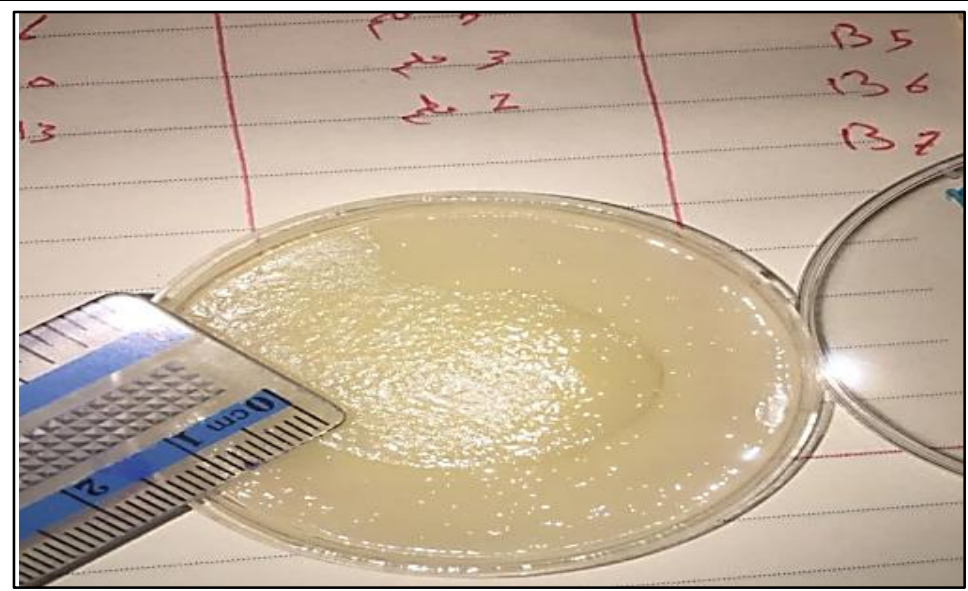

FIGURE 2. Bacillus spp colonies in the solid Pikovskayas medium that isolated from the comparison soil during the germination stage.

It relied on the diagnostic diagram shown in Figure (1) in diagnosing Bacillus spp as mentioned in [11] and the taxonomic keys in most of the previous studies [21]. The results of Tables (2) showed that the isolates (B1, B5, B6, B7, B11, B15, B18, B19, B22, B23, B26) isolated during the growth stages of halophytes wild plants belong to Bacillus subtilis, whose cells were characterized as rod-shaped and gram-positive as shown in Figure (3), non-producing for dyes, it is mobile, positive for citrate, catalase and starch hydrolysis tests, and has the ability to consume glucose, negative for the oxidase test, and it does not have the ability to consume maltose, growing at a temperature of $55^{\circ} \mathrm{C}$ [2], also in the medium containing $\mathrm{NaCl} 7 \%$ and the medium with $\mathrm{pH}(7)$ and its inability to grow in the medium with $\mathrm{pH}$ (5 and 10), these characteristics correspond with the morphological and biochemical characteristics of Bacillus subtilis [4,9,21]. As for the rest of the isolates, they belonged to Bacillus megaterium, and this is consistent with [22,7], who confirmed the possibility of isolating this bacterium from the rhizosphere of Iraqi soils, as it is efficient in the tolerance the problems of most the Iraqi soils with high levels of salinity, which affects significantly on the activity of microorganisms in soils [23].

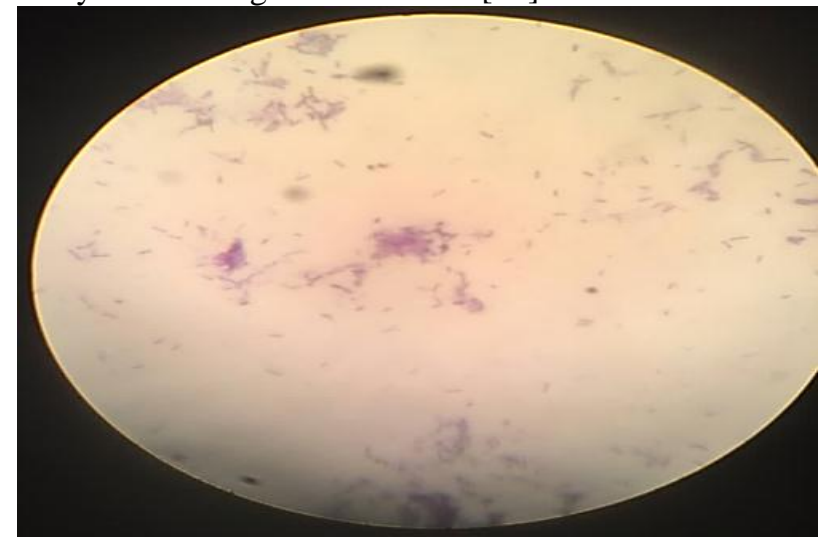

FIGURE 3. Bacillus spp at magnification power 40X.

- Efficiency of Bacillus spp isolates in dissolving tri-calcium phosphate Ca3(Po4)2 and changing the pH of the liquid medium after inoculation

Table (2) showed the variation in the ability of the isolates to dissolve phosphate and the change in the reaction degree of the liquid medium after incubation, as isolate B2 and isolate B1 recorded the highest solubility coefficient of (1.50, 1.40), respectively, and the $\mathrm{pH}$ of the medium changed to $(5.08,5.40)$ of the two types $B$. megaterium and B. subtilis, respectively, and this reflects an inverse relationship between the solubility coefficient (the dissolved amount of phosphate) and the $\mathrm{pH}$ value of the medium in which the dissolution occurs. Its efficiency in dissolving phosphate is estimated by the ability of biochemical microorganisms to produce the quantity and quality of secreted organic acids, this was confirmed by $[18,4]$ that Bacillus spp produces a different group of organic acids, which works to reduce the $\mathrm{pH}$ of the rhizosphere and the most important are lactic acid, succinic acid and citric acid. Also, there was a clear variation between the isolates in the values of the solubilization coefficient and $\mathrm{pH}$ values of medium after incubation, as the isolate B26, belonging to the species $B$. subtilis, gave a solubilization coefficient of 1.34 and reduced $\mathrm{pH}$ value to 4.81, this variation between organisms can be attributed to their genetic difference in the coding for the production of different organic acids, especially lactic acid and 2ketogluconic acid, which proved their effectiveness in reducing the value of the degree of reaction of the medium and the dissolution of phosphates. The dissolution of phosphate by these types of bacteria, which made them a candidate to be one of the most important growth-promoting organisms and as an effective bio-fertilizer to improve plant nutrition with 
phosphorous and as a vital pollinator to increase the availability of phosphorous in the soil and to reduce the addition of mineral fertilizers, which reduces the impact of pollution and costs of agriculture $[21,23]$.

\section{IV.CONCLUSION}

The findings of isolation and diagnosis showed the spread of Bacillus sp in the Iraqi saline environments that belonged to Bacillus subtilis and Bacillus megaterium, which they proved their effectiveness in dissolving phosphate and changing the $\mathrm{pH}$ of the liquid medium.

TABLE 2. Some phenotypic, microscopic and biochemical characteristics of Bacillus spp.

\begin{tabular}{|c|c|c|c|c|c|c|c|c|c|c|c|c|c|c|c|c|c|c|c|}
\hline \multirow[b]{2}{*}{ 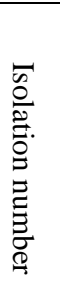 } & \multicolumn{3}{|c|}{$\begin{array}{l}\text { Microscopic } \\
\text { features }\end{array}$} & \multicolumn{2}{|c|}{$\begin{array}{l}\text { Phenotypic } \\
\text { features }\end{array}$} & \multicolumn{3}{|c|}{$\begin{array}{c}\text { Carbon } \\
\text { consumption }\end{array}$} & \multicolumn{8}{|c|}{ Biochemical tests } & \multirow[b]{2}{*}{ 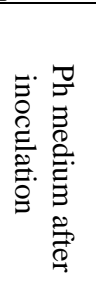 } & \multirow[b]{2}{*}{ 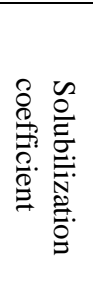 } & \\
\hline & 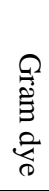 & 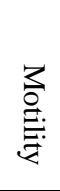 & 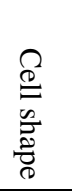 & 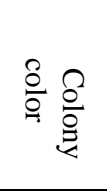 & $\stackrel{n}{\stackrel{0}{0}} \stackrel{0}{\varrho}$ & 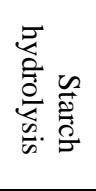 & $\frac{3}{\frac{3}{0}}$ & 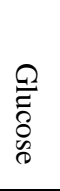 & 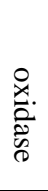 & 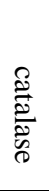 & 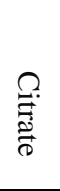 & 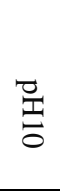 & 穿 & 党 & $\begin{array}{l}u \\
u \\
\circ\end{array}$ & $\begin{array}{l}Z \\
\stackrel{2}{0} \\
\vec{a} \\
09\end{array}$ & & & \\
\hline B1 & + & + & $\begin{array}{c}\text { Ro } \\
\text { d }\end{array}$ & White & Circular & + & - & + & - & + & - & - & + & - & + & + & $\begin{array}{c}5.4 \\
0\end{array}$ & 1.40 & B.su \\
\hline B2 & + & + & $\begin{array}{l}\text { Ro } \\
\text { d }\end{array}$ & Brown & Lobed & + & - & - & + & - & + & + & + & + & - & + & $\begin{array}{c}5.0 \\
8\end{array}$ & 1.50 & B.me \\
\hline B3 & + & + & $\begin{array}{l}\text { Ro } \\
\text { d }\end{array}$ & Brown & $\begin{array}{c}\text { Spherica } \\
1\end{array}$ & + & - & - & + & - & + & + & + & + & - & + & $\begin{array}{c}5.2 \\
5\end{array}$ & 1.28 & B.me \\
\hline B4 & + & + & $\begin{array}{l}\text { Ro } \\
\text { d }\end{array}$ & White & Circular & + & - & - & + & + & + & + & + & + & - & + & $\begin{array}{c}5.1 \\
8\end{array}$ & 1.37 & B.me \\
\hline B5 & + & + & $\begin{array}{c}\text { Ro } \\
\text { d }\end{array}$ & Brown & $\begin{array}{c}\text { Spherica } \\
1\end{array}$ & + & - & - & - & + & + & + & + & - & + & + & $\begin{array}{c}5.5 \\
1\end{array}$ & 1.30 & B.su \\
\hline B6 & + & + & $\begin{array}{c}\text { Ro } \\
\text { d }\end{array}$ & Brown & Circular & + & - & - & - & - & + & + & + & - & + & + & $\begin{array}{c}5.2 \\
6\end{array}$ & 1.33 & B.su \\
\hline B7 & + & + & $\begin{array}{l}\text { Ro } \\
\text { d }\end{array}$ & White & $\begin{array}{c}\text { Spherica } \\
1\end{array}$ & + & - & - & - & + & + & + & + & - & + & + & $\begin{array}{c}5.0 \\
5\end{array}$ & 1.23 & B.su \\
\hline B8 & + & + & $\begin{array}{l}\text { Ro } \\
\text { d }\end{array}$ & Brown & Serrated & + & - & + & + & - & + & + & + & + & - & + & $\begin{array}{c}5.5 \\
1\end{array}$ & 1.22 & B.me \\
\hline B9 & + & + & $\begin{array}{l}\text { Ro } \\
\text { d }\end{array}$ & White & $\begin{array}{c}\text { Spherica } \\
1\end{array}$ & + & - & - & + & + & + & + & + & + & - & + & $\begin{array}{c}5.4 \\
0\end{array}$ & 1.33 & B.me \\
\hline B10 & + & + & $\begin{array}{c}\text { Ro } \\
\text { d }\end{array}$ & $\begin{array}{l}\text { Yello } \\
\text { w }\end{array}$ & Circular & + & - & + & + & + & + & + & + & - & - & + & $\begin{array}{c}5.6 \\
1\end{array}$ & 1.25 & B.me \\
\hline B11 & + & + & $\begin{array}{l}\text { Ro } \\
\text { d }\end{array}$ & White & Circular & + & - & - & + & + & + & - & + & - & + & + & $\begin{array}{c}5.1 \\
2\end{array}$ & 1.23 & B.su \\
\hline B12 & + & + & $\begin{array}{l}\text { Ro } \\
\text { d }\end{array}$ & $\begin{array}{c}\text { Yello } \\
\text { w }\end{array}$ & $\begin{array}{c}\text { Spherica } \\
1\end{array}$ & + & - & + & + & + & + & + & + & + & - & + & $\begin{array}{c}5.2 \\
3\end{array}$ & 1.26 & B.me \\
\hline B13 & + & + & $\begin{array}{l}\text { Ro } \\
\text { d }\end{array}$ & $\begin{array}{c}\text { Yello } \\
\text { w }\end{array}$ & Convex & + & - & - & + & + & + & + & + & + & - & + & $\begin{array}{c}4.9 \\
0\end{array}$ & 1.31 & B.me \\
\hline B14 & + & + & $\begin{array}{l}\text { Ro } \\
\text { d }\end{array}$ & White & Serrated & + & - & - & + & + & + & + & + & - & - & + & $\begin{array}{c}4.9 \\
1\end{array}$ & 1.26 & B.me \\
\hline B15 & + & + & $\begin{array}{l}\text { Ro } \\
\text { d }\end{array}$ & $\begin{array}{c}\text { Yello } \\
\text { w }\end{array}$ & Convex & + & - & - & + & + & + & - & + & - & + & + & $\begin{array}{c}5.0 \\
9\end{array}$ & 1.15 & B.su \\
\hline B16 & + & + & $\begin{array}{l}\text { Ro } \\
\text { d }\end{array}$ & $\begin{array}{l}\text { Yello } \\
\text { w }\end{array}$ & Flat & + & - & + & + & + & + & + & + & + & - & + & $\begin{array}{c}5.5 \\
4\end{array}$ & 1.09 & B.me \\
\hline B17 & + & + & $\begin{array}{c}\text { Ro } \\
\text { d }\end{array}$ & $\begin{array}{l}\text { Yello } \\
\text { w }\end{array}$ & $\begin{array}{c}\text { Spherica } \\
1\end{array}$ & + & - & + & + & + & + & + & + & + & - & + & $\begin{array}{c}5.0 \\
3\end{array}$ & 1.22 & B.me \\
\hline B18 & + & + & $\begin{array}{l}\text { Ro } \\
\text { d }\end{array}$ & White & Circular & + & - & - & + & + & + & - & + & + & + & + & $\begin{array}{c}5.4 \\
5\end{array}$ & 1.10 & B.su \\
\hline B19 & + & + & $\begin{array}{l}\text { Ro } \\
\text { d }\end{array}$ & White & Convex & + & - & + & - & + & + & + & + & - & + & + & $\begin{array}{c}5.6 \\
5\end{array}$ & 1.13 & B.su \\
\hline B20 & + & + & $\begin{array}{l}\text { Ro } \\
\text { d }\end{array}$ & $\begin{array}{c}\text { Yello } \\
\text { w }\end{array}$ & Convex & + & - & - & + & + & + & + & + & + & - & + & $\begin{array}{c}5.6 \\
0\end{array}$ & $\begin{array}{c}1.18 \\
8\end{array}$ & B.me \\
\hline B21 & + & + & $\begin{array}{l}\text { Ro } \\
\text { d }\end{array}$ & White & Lobed & + & - & + & + & + & + & - & + & + & - & + & $\begin{array}{c}5.5 \\
3\end{array}$ & 1.25 & B.me \\
\hline B22 & + & + & $\begin{array}{c}\text { Ro } \\
\text { d }\end{array}$ & Brown & Serrated & + & - & + & - & + & + & - & + & - & + & + & $\begin{array}{c}5.7 \\
1\end{array}$ & 1.28 & B.su \\
\hline B23 & + & + & $\begin{array}{c}\text { Ro } \\
\text { d }\end{array}$ & $\begin{array}{l}\text { Yello } \\
\text { w }\end{array}$ & Serrated & + & - & + & - & + & + & + & + & - & + & + & $\begin{array}{c}5.4 \\
7\end{array}$ & 1.22 & B.su \\
\hline B24 & + & + & $\begin{array}{c}\text { Ro } \\
\text { d }\end{array}$ & $\begin{array}{c}\text { Yello } \\
\text { w }\end{array}$ & Convex & + & - & - & + & + & + & + & + & + & - & + & $\begin{array}{c}5.3 \\
5 \\
\end{array}$ & 1.16 & B.me \\
\hline
\end{tabular}




\begin{tabular}{|c|c|c|c|c|c|c|c|c|c|c|c|c|c|c|c|c|c|c|c|}
\hline B25 & + & + & $\begin{array}{c}\text { Ro } \\
\text { d }\end{array}$ & $\begin{array}{c}\text { Yello } \\
\text { w }\end{array}$ & Lobed & + & - & - & - & + & + & - & + & + & - & + & $\begin{array}{c}5.4 \\
8\end{array}$ & 1.20 & B.me \\
\hline B26 & + & + & $\begin{array}{c}\text { Ro } \\
\text { d }\end{array}$ & Brown & Serrated & + & - & + & - & + & + & + & + & - & + & + & $\begin{array}{c}4.8 \\
1\end{array}$ & 1.34 & B.su \\
\hline B27 & + & + & $\begin{array}{c}\text { Ro } \\
\text { d }\end{array}$ & $\begin{array}{c}\text { Yello } \\
\text { w }\end{array}$ & Convex & + & - & - & + & + & + & + & + & + & - & + & $\begin{array}{c}5.6 \\
3\end{array}$ & 1.21 & B.me \\
\hline
\end{tabular}

B.su = Bacillus subtilis, B.me= Bacillus megaterium

\section{REFERENCES}

[1] M. Rashid, Khalil, S., Ayub, N., Alam, S., and Latif, A. (2004). Organic acids production and phosphate Solubilization by phosphate solubilizing microorganisms (PSM) under in vitro conditions. Pak. J, Biol. Sci, 7: 187-197.

[2] S. A. A. Attia, Kazem L. A., Maid S. K., and Moaibed H. W . (2019). Study of some optimal conditions for the biological activity of Bacillus subtilis in degrading cellulose. Iraqi Journal of Science and Technology 10(2):1-7.

[3] E. Firew, Delelegn W., and Muleta, D.(2016). Phosphate Solubilization Potential of Rhizosphere fungi Isolated from Plants in jimma zon, southwest Ethiopia. Hindawi Publishing corporation International journal of Microbiology. Volume 2016, Article ID 5472601, 11.

[4] Abdul Ridha and Jabbar, A. K . (2015). Isolation and identification of Bacillus subtilis and testing its efficiency in dissolving solid phosphate in liquid cultures. Al-Muthanna Journal of Agricultural Sciences. 3(1): 1-7.

[5] Sundara, Rao W V B, Sinha M K.(1963). Phosphate dissolving microorganisms in the soil and rhizosphere. Indian j. Agric. Sci,33:272-288.

[6] N. A. Logan, and De Vos, P. (2009). Genus Bacillus in: Bergeys manual of systematic bacteriology, second Edition, vol. 3, springer Dordrecht Heidelberg London New York. pp: 121-128.

[7] S. D. J. Al-Sahlani, (2015). Isolation and identification of Bacillus cereus and its use in the production of polyhydroxybutyrate. $\mathrm{PhD}$ thesis, College of Agriculture and Food Sciences, University of Basra.

[8] M. A. Abdel Qader, and Sharif, A. Y . (2011). Isolation and identification of Bacillus species from locally prepared juices in the city of Mosul. Journal of Education and Science. 24(4): 28-36.

[9] Y. Chiu, Rekha, Wei, L., Aruna, A. (2006). Encapsulation of plant growth promoting bacteria in Alginate beads enriched with Humic acid. Wileyinter sci., 76-83.

[10] S. Donca, , Nimit, S. M.., Octavita E. A. (2005). Microbiological study of Bacillus megaterium strain with soil phosphors solubilzation potential. Paint Biol. Volumes, 49-50, p. 31-39.

[11] E. Koneman, Allen S., Janda W., and Winn W. (1997). "Color Atlas and Textbook of Diagnostic Microbiology". ${ }^{\text {th }}$ ed., Lippincott-Raven Publishers, Philadelphia, USA.

[12] C.A. Black, (1965). Methods of soil analysis .part(1).physical and mineralogical soil properties An .Soc. Agrononmy. Inc. puplisher Madison, Wisconsin, USA.

[13] P. R. Murray, Baron, E. J., Jorgensen, J. H., Landry, M. L. and Pfaller M. A. (2007). Manual of Clinical Microbiology. $9^{\text {th }}$ (ed). Washington, DC. American Cociety for Microbiology, USA.

[14] A. E. Brown, and Smith, H. R. (2017). Benson's Microbiological Applications, Laboratory Manual in General Microbiology $14^{\text {th }}$ (ed). Mc Graw-Hill Higher Education. New York. 438pp.

[15] W. F. Harrigan, and McCance, M. E. (1976). Laboratory Methodsin Food and dairy Microbiology. Academic Press, London

[16] R. M. Smibert, and Krieg, N.R.(1981).General characterization .In: Sneath P.H. MURRAY,R.G.E., and costilow, R. N., Nester, E.W., Wood, W. A., Krieg, Philips, G, P.(eds). Manual of Methodes for general bacteriology: 409-443.

[17] E. J. Baron, and Finegold, S. M. (1990). Diagnostic microbiology. $8^{\text {th }}$. (ed). The C. V. Mosby company.

[18] K. A. Hassan, (2012). Isolation of phosphate-dissolving bacteria from soils and identification of organic acids produced from them. Iraqi Journal of Agricultural Sciences. 43(6): 72-77.

[19] M. Edi-premono, , Moawad, M. A., Vleck, P. L. G. (1996). Effect of phosphate Solubilizing Pseudomonas putida on the growth of maize and its survival in the rhizosphere. Indonesian Journal of crop Science. 11, 13-23.

[20] A. T. Hikmat, (2019). Effect of some physical and chemical factors on the growth of Bacillus subtilis and the production of Xylanase enzyme. Journal of Education and Science. 28(1): 64-78.

[21] G. D. Saha, Chosh, P. A.,Isha, M.,and Saha, A.(2012). Isolation and of characteristincs tow new Bacillus subtilis strains from the rhizosphere of eggplant as potential biocontrol agents. J of plant pathology.94,1:109-118.

[22] H. A. S. Radi, , Abdul-Rida, H. A., and Hadwan., H. A. (2018). Isolation and identification of Bacillus megaterium from the rhizosphere of different crops, testing its efficiency in dissolving phosphate in liquid and solid culture media, and testing its growth with Bacillus subtilis and Bacillus mucilaginous bacteria as a fertilizer combination. Iraqi Journal of Soil Science. 18(1):214-223.

[23] Y. Andriani, , Rochimia. E, Ranayuning R. and Rtuee S,. (2017). Characterization of Bacillus megaterium and Bacillus mycoides Bacteria as probiotic Bacteria in fich and shrimp feed. In $2^{\text {nd }}$ international conference on sustainabie Agriclture and food. Pag 127-135. Dol 10. 18502b/kls. V zi 6. 1029. 